Андрійцьо-Рузаєва А. Ю., асистент кафедри менеджменту Задорожна І. Д., здобувач вищої освіти першого (бакалаврського) рівня (Національний університет водного господарства та природокористування, м. Рівне)

\title{
ПОРІВНЯЛЬНИЙ АНАЛІЗ СКЛАДОВИХ САМОМЕНЕДЖМЕНТУ ЗА МОДЕЛЛЮ Р. С. ШАРМИ НА ОСНОВІ ХРИСТИЯНСЬКОГО СВІТОГЛЯДУ
}

\begin{abstract}
Стаття присвячена аналізу основних складових моделей самоменеджменту. Здійснено крос-культурне дослідження прийомів поведінки у контексті християнської культури та індуїзму. Проведено апробацію порівняння складових моделі самоменеджменту Робіна Шарми зі складовими, які ґрунтуються на християнській етиці. Виявлено спільні та відмінні структурні елементи порівнювальних моделей.
\end{abstract}

Ключові слова: модель самоменеджменту; складові; метод та процедура порівняння; прийоми самоуправління; християнство; буддизм.

Людина - це пілігрим, адже сучасний світ плюральний, сповнений дихотомій. Сучасна молодь впевнено відходить від авторитету минулого i прагне вибудувати власну модель самоорганізації опираючись на світоглядні парадигми, що мають яскраво виражений релігійний характер. На допомогу шукачам власних цілей, ідеалів, сенсу життя приходять поширені західні і східні культури. А відтак, до прикладу, люди, що народились i виховувалися у дусі протестантизму згодом переходять у православ'я, невіруючі люди знаходять віру, часто приймають буддизм. Яскравим прикладом можуть слугувати всесвітньо відомі голлівудські зірки. Актор Джонатан Джексон народився в сім"ї адвентистів, але кілька років тому прийняв православ'я разом зі своєю родиною [1]. Орландо Блум після важкої травми зміг почати рухатися лише завдяки заняттям хатха-йогою, у буддизмі він знайшов внутрішню гармонію і спокій [2]. Одних приваблює чиста молитва і віра у Всевишнього, інших - гармонія тіла і душі, управління свідомістю.

Кожна людина - це єднання розуму, духу та поривання, прагнучи віднайти власний абсолют вона звертається до різних теорій, релігій, практик, але водночас сповідування певних норм, правил, концепцій призводить до єдиного - внутрішньої гармонії, балансу із природою, становленні у соціумі. I все заради того, щоб управляючи собою бути щасливим. Самоменеджмент на 
сьогоднішній день є надзвичайно актуальним і відповідно стрімко розвивається.

В концептуальному плані вивчення самоменеджменту починається із Л. Зайверта, М. Вудкока і Д. Френсіса, В. Карпачова, В. Андрєєва, А. Хроленко, Х. Швальбе, у 90-х продовжують Ф. Русинов, Б. Будзан, Н. Лукашевич; у двохтисячних - К. Кінан, С. Кові, Р. Шарма, М. Орликовський, І. Добротворський, В. Колпаков, О. Крикун, А. Чкан, Т. Немченко, В. Нетепчук, Н. Лугова та інші.

Загалом на сьогоднішній день у самоменеджменті як теоретиками так і практиками, динамічно формується база знань про те, як індивід повинен себе пізнавати, керувати собою та займатися безперервним саморозвитком у всіх сферах власної життєдіяльності, пропонуючи при цьому безліч моделей.

Тому, метою дослідження $€$ порівняння моделі самоменеджменту Р.С. Шарми 3 моделлю самоменеджменту яка ґрунтується на християнській концепції.

Порівняльний аналіз (англ. comparative analysis - порівняльний аналіз) - це методологія та різновид соціологічного дослідження, метою якого $€$ виявлення відмінностей та спільних характеристик різноманітних феноменів.

Порівняння як аналітичну процедуру при вивченні соціальних явищ використовували давньогрецькі мислителі, зокрема Аристотель. Засади порівняльного дослідження у соціології сформовано за часів їі становлення як науки у XIX - на поч. XX ст. А. де Токвіль (1805-1959), Дж. С. Мілль (1806-1873), К. Маркс (18181883) та ін. цілеспрямовано застосовували порівняльний аналіз при побудові теорій суспільства [3].

Широке застосування порівняльного аналізу розпочалось у 1960-х і було пов'язане з розвитком дослідницької методології. Були вдосконалені статистичні методи і методи масових опитувань, провадилися міжнародні дослідницькі проєкти, емпіричні кроснаціональні дані яких аналізували Г. Алмонд, С. Верба, С. М. Ліпсет, М. Кон, С. Роккан та ін. Сьогодні відомими є бази крос-національних даних проєктів Всесвітнього дослідження цінностей (World Values Survey), Європейського дослідження цінностей (European Values Study), Європейського соціального дослідження (European Social Survey), до яких частково було залучено Україну [3].

Серед провідних фахівців порівняльних досліджень країн, цінностей та культур початку XXI ст. - Р.ІІнглхарт, К. Вельцель, Г. Хофстеде, Ш. Шварц та ін. Серед українських дослідників Н. Паніна, Є.Головаха, А.Горбачик тощо. Традиція М. Вебера порівняння на основі окремих випадків розвинулася у порівняльному історичному аналізі (англ. comparative historical 
analysis), зокрема у роботах Р. Бендікса, Б. Мура, Ч. Тіллі, Т. Скочпол, М. Манна, Дж. Махоні та ін. Ч. Рагін запропонував метод якісного порівняльного аналізу (QCA) на основі правил логічного висновку із застосуванням нечітких множин і булевої алгебри.

Порівняння може відбуватися в кросс-секційних (об'єкти співвідносять за визначеними критеріями) та лонгітюдних (оцінюють зміни та динаміку процесів, а також відмінності об'єктів між собою) дослідженнях. Аналіз може обмежуватись описом реальності (дескриптивний порівняльний аналіз) або мати на меті пояснення й прогнозування і використовуватись для розроблення чи уточнення теорії.

Аналітичною основою порівняння $€$ метод абстракції (абстракція ототожнення, ізолювальна, узагальнювальна, абстракція потенційної здійсненності), який дає змогу визначати спільні властивості, окремі класи та можливі зв'язки. Важливим різновидом абстрагування є ідеалізація, під час якої здійснюється перехід від реально існуючих характеристик соціальних феноменів до ідеальних типів. Ефективним сучасним методом порівняння $€$ багаторівневе статистичне моделювання (MLM), яке дає змогу розрізнити ефекти змінних, що включені до моделі, одночасно на індивідуальному та груповому рівні (наприклад, можна оцінити ефект взаємодії національного контексту з особливостями індивідуальної поведінки). у якісних соціологічних дослідженнях порівняльний аналіз фокусується на виявленні унікального історичного та культурного контексту та розумінні специфічних ситуацій з їхніми наслідками при детальному розгляді невеликої кількості випадків. Замість статистичних методів застосовуються логічні методи подібності та відмінності (Дж. С. Мілль), ідеальні типи та генетичне пояснення (М. Вебер), аналітична індукція (Ф. Знанецький), метод «обґрунтованої теорії» (англ. Grounded theory, А. Страус, Б. Глейзер).

Застосування нами порівняння як інструменту верифікації гіпотез та побудови теорій, надасть змогу відрізнити загальні складові, характеристики та фактори від унікальних тої чи іншої моделі.

Модель самоменеджменту, на думку Нетепчука В. В. - це план, що відображає цінності, принципи внутрішньої організації, якими керуються самоорганізуючі системи задля досягнення поставлених цілей. Модель самоменеджменту - це певна концепція поведінки, що обирає особа у керуванні своїми думками, словами, вчинками [4].

Модель самоменеджменту вибудована за теорією Робіна Шарми на основі книги «Монах, який продав свій феррарі» видана у 18 країнах та перекладена 70 мовами. Видавництво HarperCollins Canada отримало від компанії SMG Pictures пропозицію зняти фільм 
за книгою [5]. Серія книг «Монах, який продав свій Феррарі» національний бестселер у США, а у Канаді продано понад 200000 примірників цієї серії. Дана книга $€$ головним бестселером в Ізраїлі (107 тижнів у національному списку бестселерів), № 7 в Індії, № 6 в Об'єднаних арабських Еміратах, в Пуэрто Ріко (2-х річний бестселер) [6].

На думку Р. Калугіна книги Робіна Шарми стали настільними: у таких політичних лідерів, як колишній прем'єр-міністр Ізраїлю і лауреат Нобелівської премії Шимон Перес; суперзірки американської Суперліги Карлос Дельгадо (який сказав, що книга «Монах, який продав свій Феррарі» справила на нього найбільше враження з усіх прочитаних ним книг), гравця San Francisco Giants Круза-молодшого та Джесса Палмера, зірки Голлівуду Мішель Йео. Зірка поп-музики Рікі Мартін та Бон Джові читають усі книги Робіна Шарми та $€$ великими прихильниками даної моделі саморозвитку [7]. Список можна продовжувати довго, тому що тільки за останні 5 років було продано більше 1 мільйона примірників цієї книги.

Загалом, 39-річний Робін є автором 7 книг (6 міжнародних бестселерів, із яких три - № 1 у світі), є одним із провідних світових експертів у питаннях лідерства, професійного і особистого розвитку. Він часто виступає поряд з Біллом Клінтоном, Джеком Уелчем, Крістофером Рівом, Дипаком Чопрой та доктором Філом. Також Робін багато співпрацює 3 менеджерами - міліардерами, головними виконавчими директорами та відомими бізнесменами, які представляють більше 500 гігантських корпорацій до яких належать Microsoft, Panasonic, IBM, FedEx, General motors, Kraft. Компанія Р. Шарми діє у 50 країнах світу під гаслом: «Допоможемо людям у всьому світі лідирувати без титулів і звань» [8].

Як відомо, одна з головних свобод глобального демократичного суспільства - свобода віросповідання, і відомі особистості охоче користуються нею, пропагуючи ту релігію, яка їм до душі. Розглянемо до прикладу - буддизм. Яскравими прихильниками якого є такі зірки з наступними висловлюваннями:

Річард Гір: «Буддизм - моя провідна зірка»;

Ума Турман: «Буддизм справив на мене величезний вплив»;

Шер: «Не релігія, а філософія»;

Орландо Блум: «Буддизм - це щоденне духовне зростання»;

Тіна Тернер: «Буддизм подарував мені нове життя».

Буддизмом в різний час також захоплювалися Альберт Ейнштейн, Джон Леннон, Стінг, Бред Пітт, Джордж Лукас, Стівен Сігал, Стів Джобс, Кіану Рівз, Леонард Коен, Джекі Чан, Робін Вільямс, Кортні Лав, Шерон Стоун, Наомі Уоттс, Дженніфер Лопес, Міранда Керр, Орнелла Муті, Кейт Мосс та інші [2]. 
Незаперечним фактом $€$ зростаючий вплив православ'я. Найвпливовіші з представників масової культури - актори, режисери та виконавці - Джеймс Белуші, Том Хенкс, Мілла Йовович, Дженніфер Еністон, Джонатан Джексон, Емір Кустуріца, Дейв Ган, Боб Марлі, американський актор японського походження КеріХіроюкі Тагава, Крістіан Бейл. На їхніх фільмах і піснях, ціннісних орієнтирах виховується глядач, наслідує їх поведінку [1].

Таким чином, книга Р. Шарми, що стала бестселером багатьох країн світу приваблює сучасну інтелігенцію та зачаровує молодь, яка знаходиться у пошуку сенсу життя, виходу з духовної кризи, занурює у давню, якій більше ніж 5 тисяч років, культуру «мудреців Сівани», яка як модель закликає змінити життя, відкрити дієві, мудрі практичні знання, які вчать: позитивно мислити; жити у відповідності до покликання; усвідомлювати силу розуму та діяти мужньо; берегти час як найбільший скарб; цінувати взаємостосунки з іншими людьми; жити теперішнім [9].

Метою нашого дослідження $€$ апробація порівняння складових моделі самоменеджменту Р. Шарми зі складовими, які ґрунтуються на етиці християн східного обряду (див. таблицю). Процедура порівняння складатиме 2 етапи: формулювання критеріїв порівняння та інтерпретація спільного та відмінного.

Порівняння моделі самоменеджменту Р. С. Шарми 3 моделлю самоменеджменту, яка ґрунтується на християнській концепції переконує у тому, що сучасна людина у виборі способу самоуправління собою керується популярністю тієї чи іншої концепції. Порівняльний аналіз дав змогу оцінити подібність обох моделей, а також те, що вони зумовлюють єдиний результат - життя у гармонії із зовнішнім та внутрішнім світом. Загалом модель християнського самоменеджменту подекуди кардинально відрізняється від буддистської, виявлено 9 протилежностей (в таблиці виділено підкресленням). Яскравим прикладом цього може слугувати сироїдство та веганство, які, попри свою популярність, досі сприймаються людьми як виключення з правил, слідування за модою, а не способом здорового способу життя та духовного очищення. Зокрема, українські дієтологи наголошують: «Не слід забувати, що саме термічна обробка попереджає харчові отруєння та інфікування,... сироїдіння повноцінним харчуванням назвати не можна» [21]. 


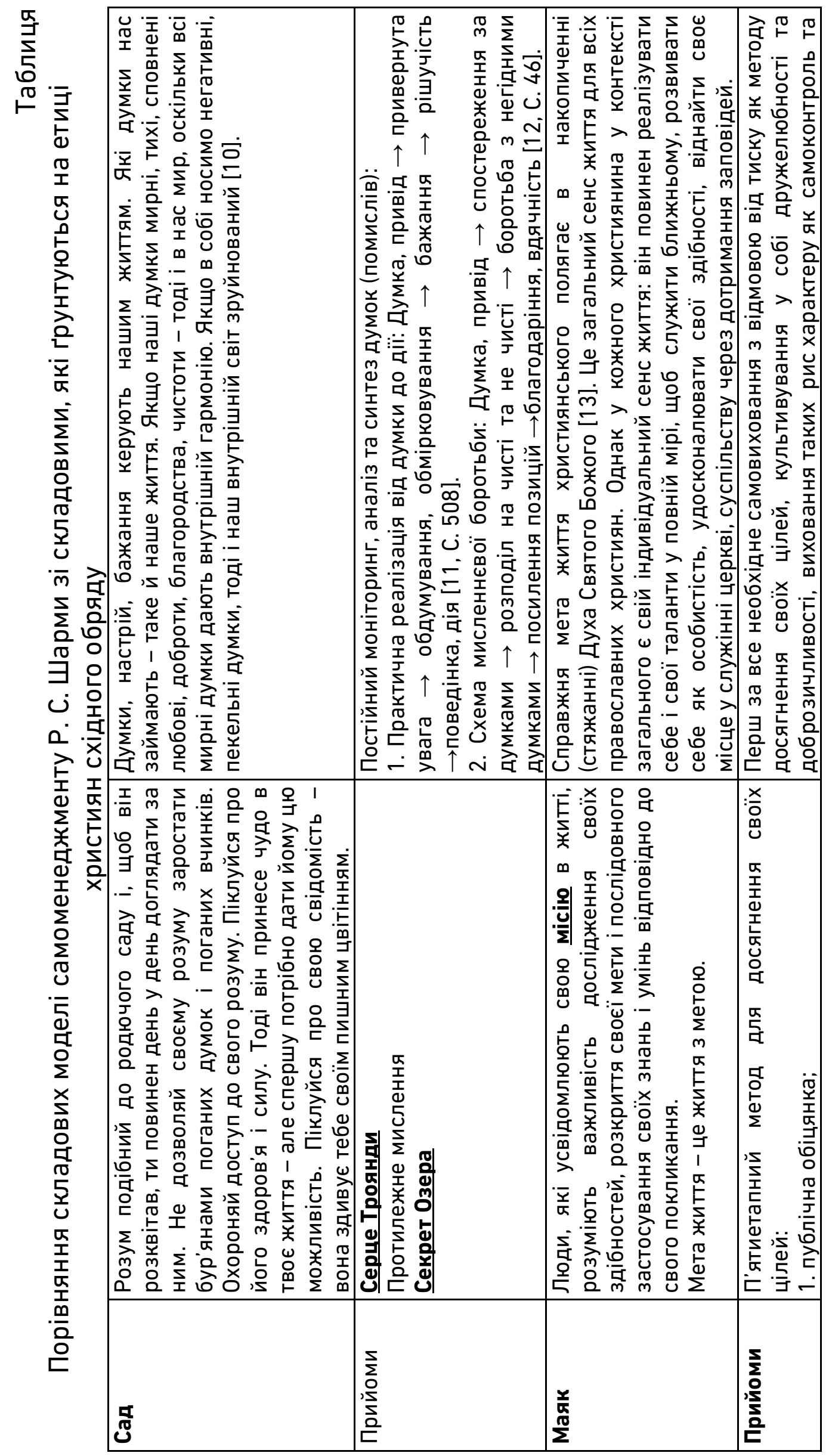




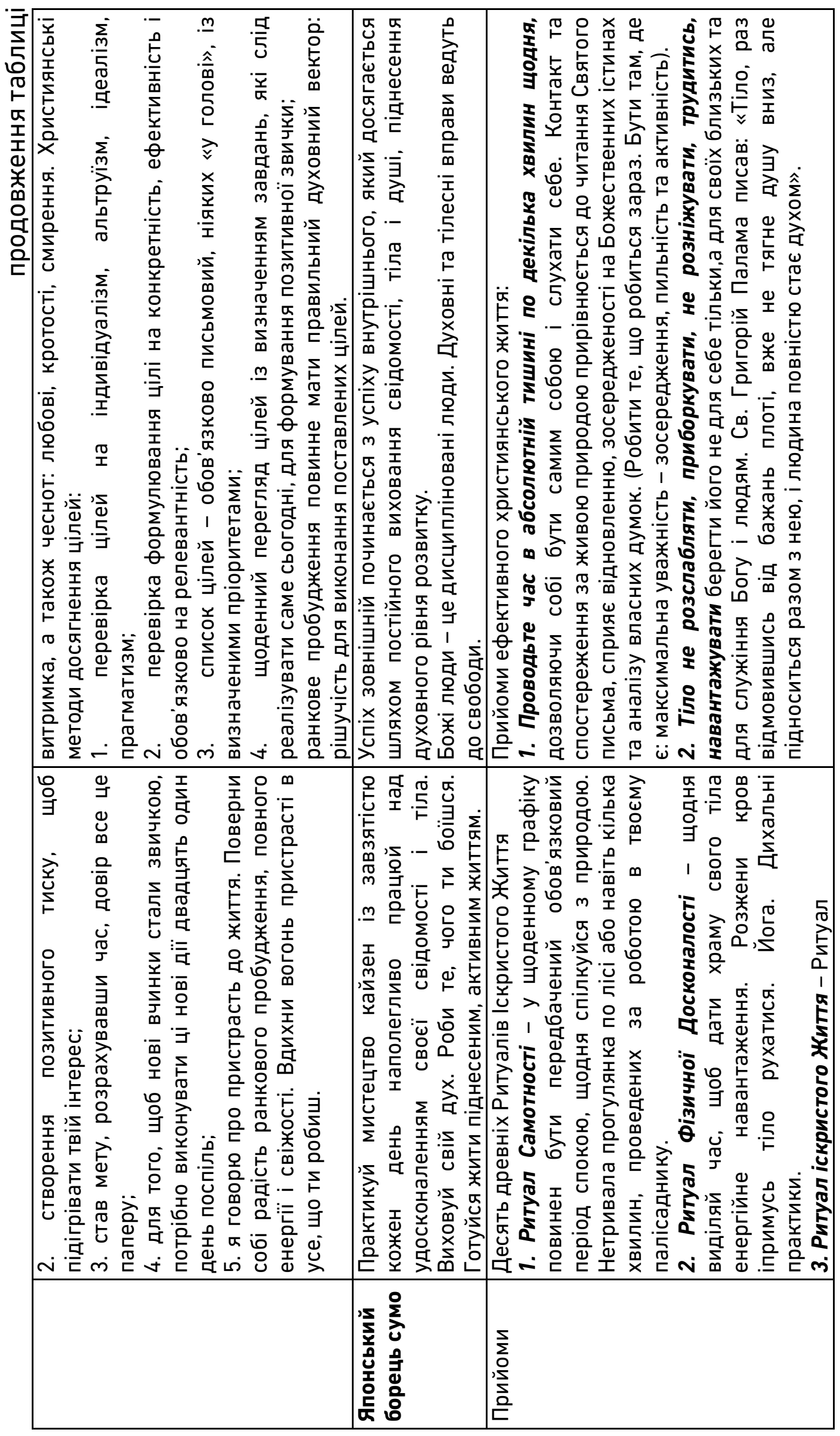




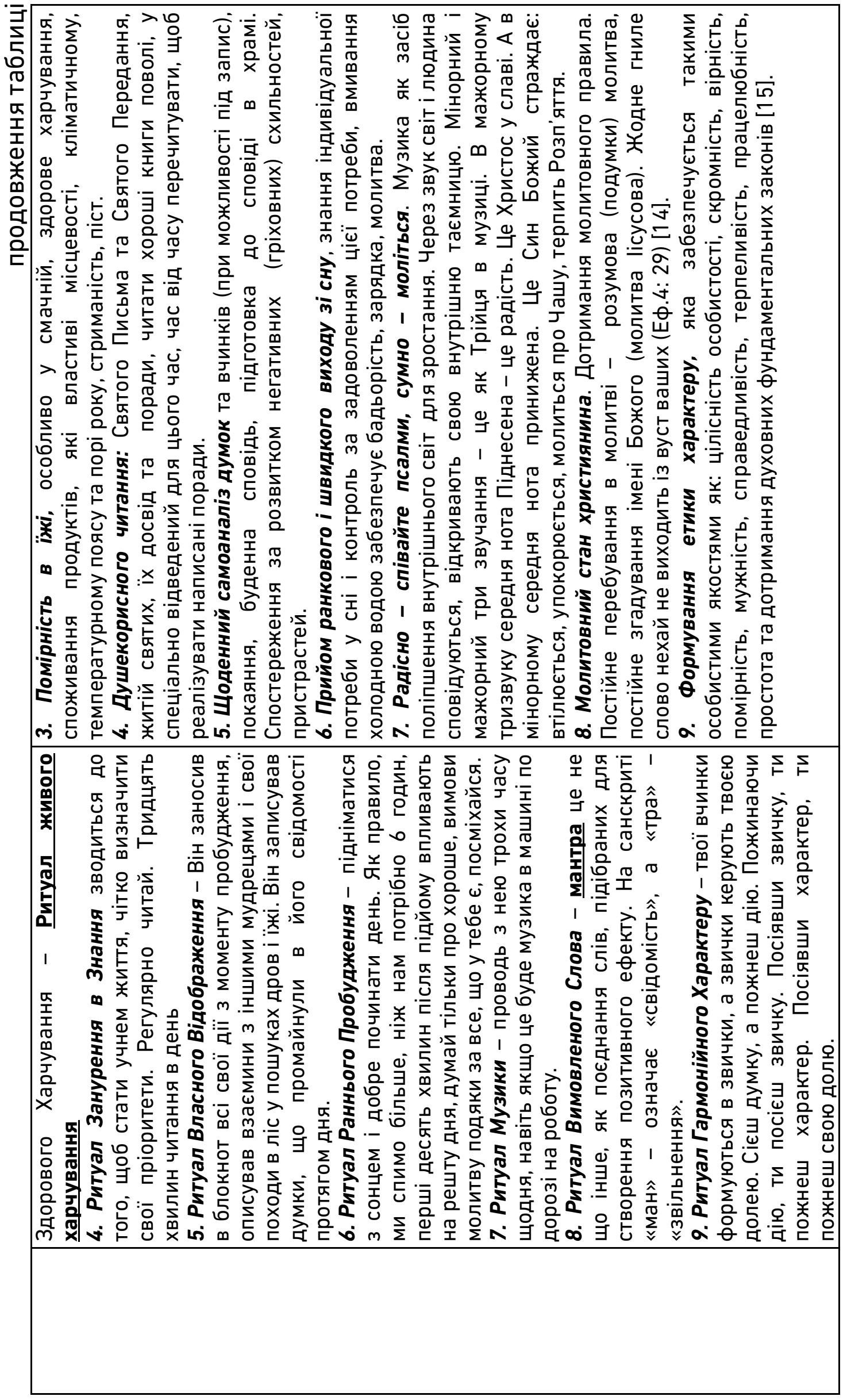




\begin{tabular}{|c|c|c|c|c|c|}
\hline 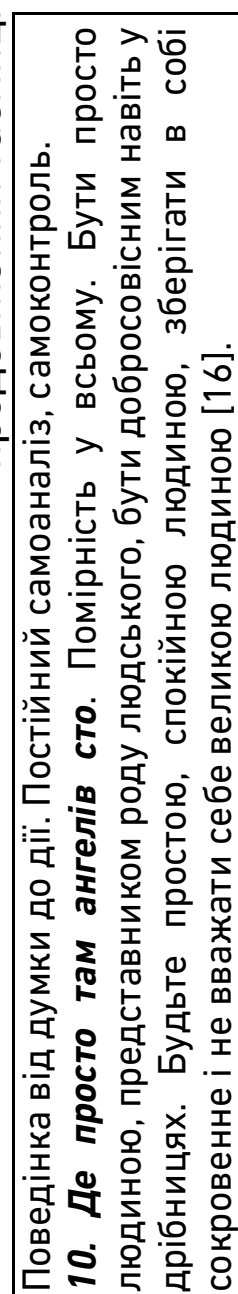 & 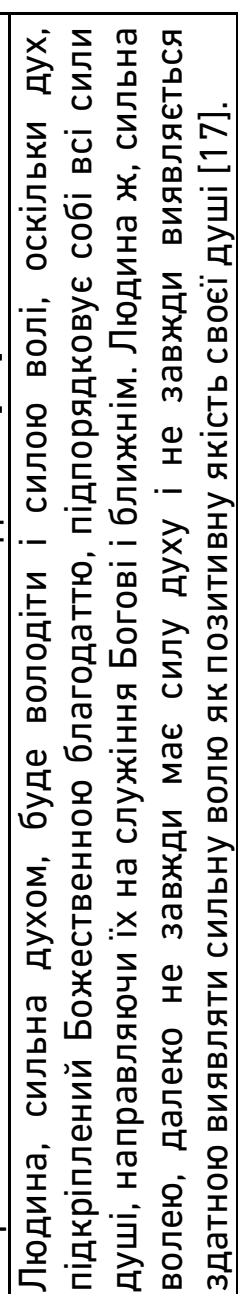 & 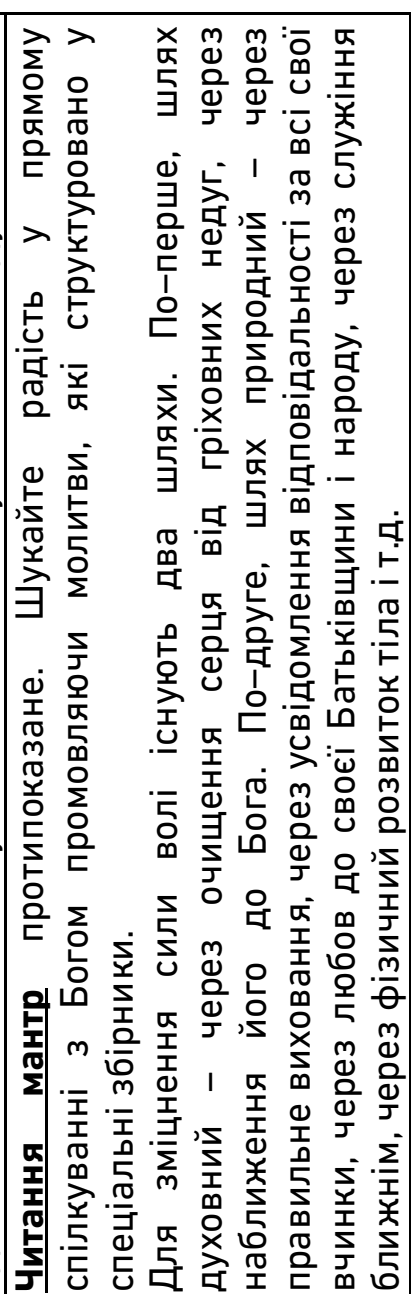 & 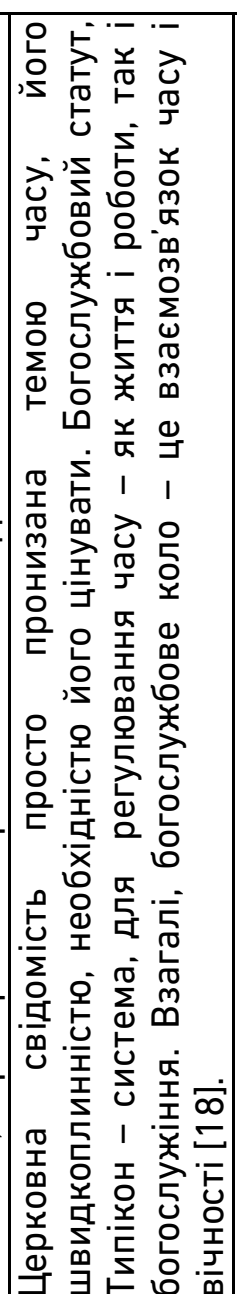 & 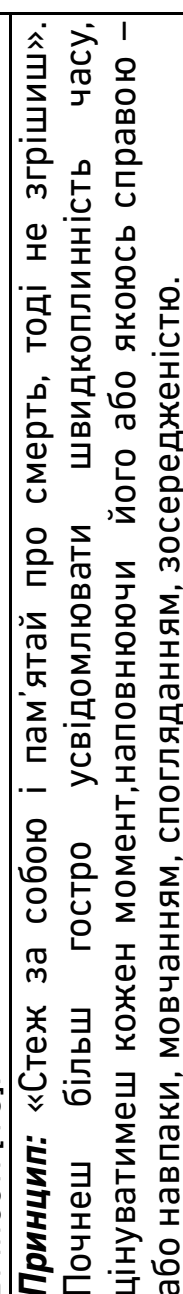 & 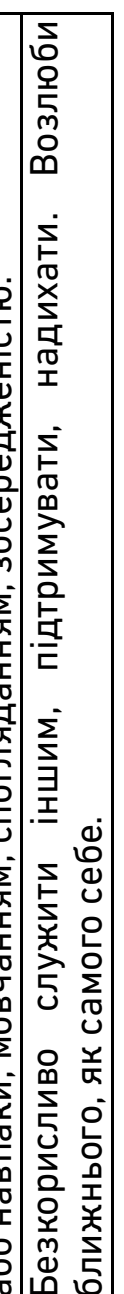 \\
\hline 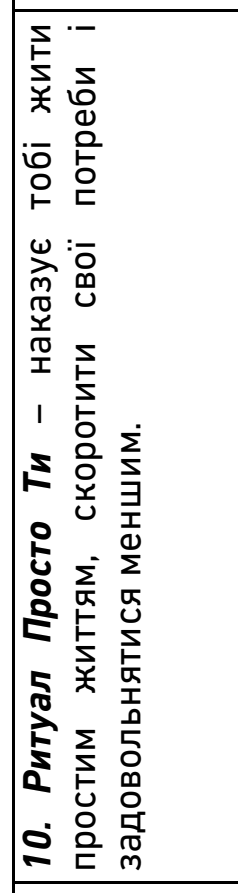 & 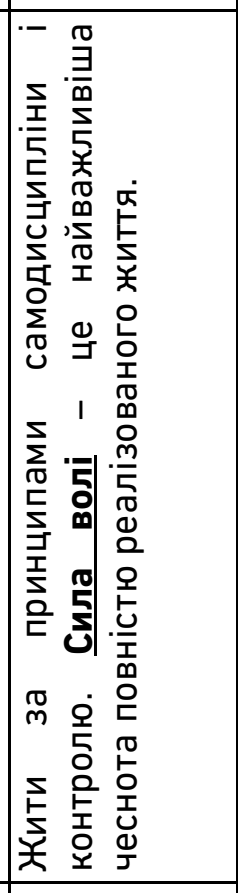 & 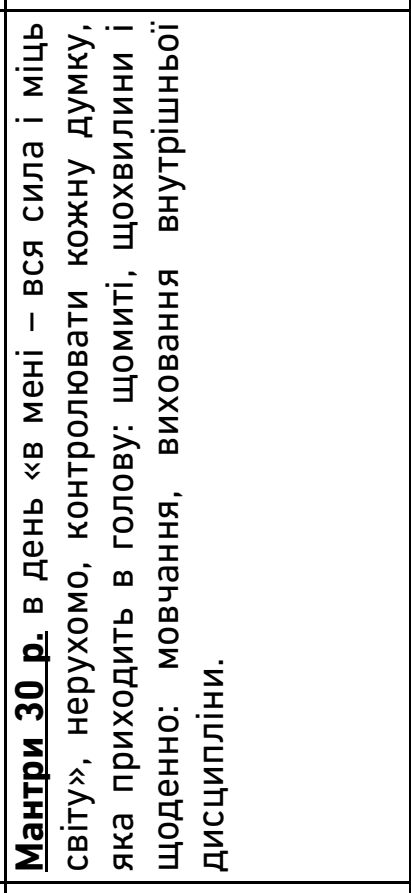 & 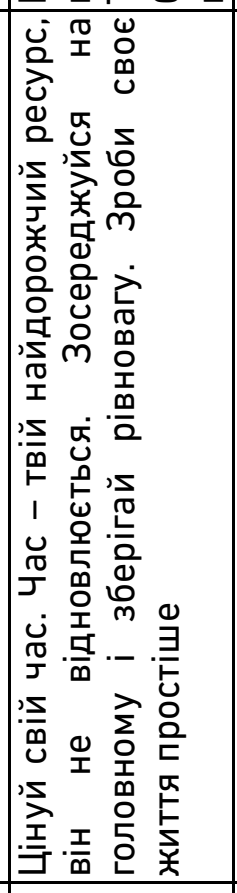 & 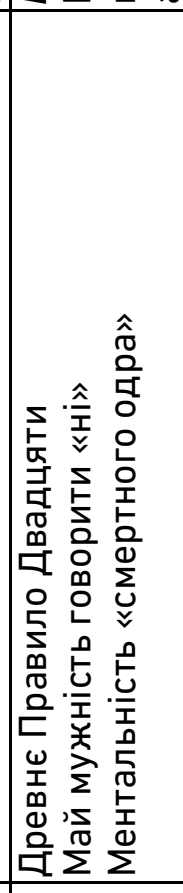 & 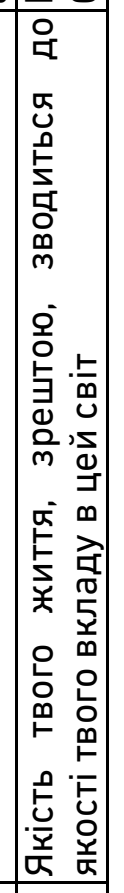 \\
\hline & 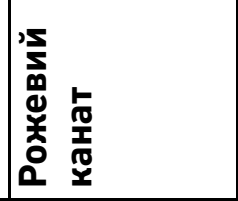 & & & 읃 & 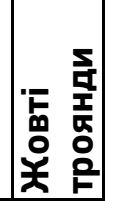 \\
\hline
\end{tabular}




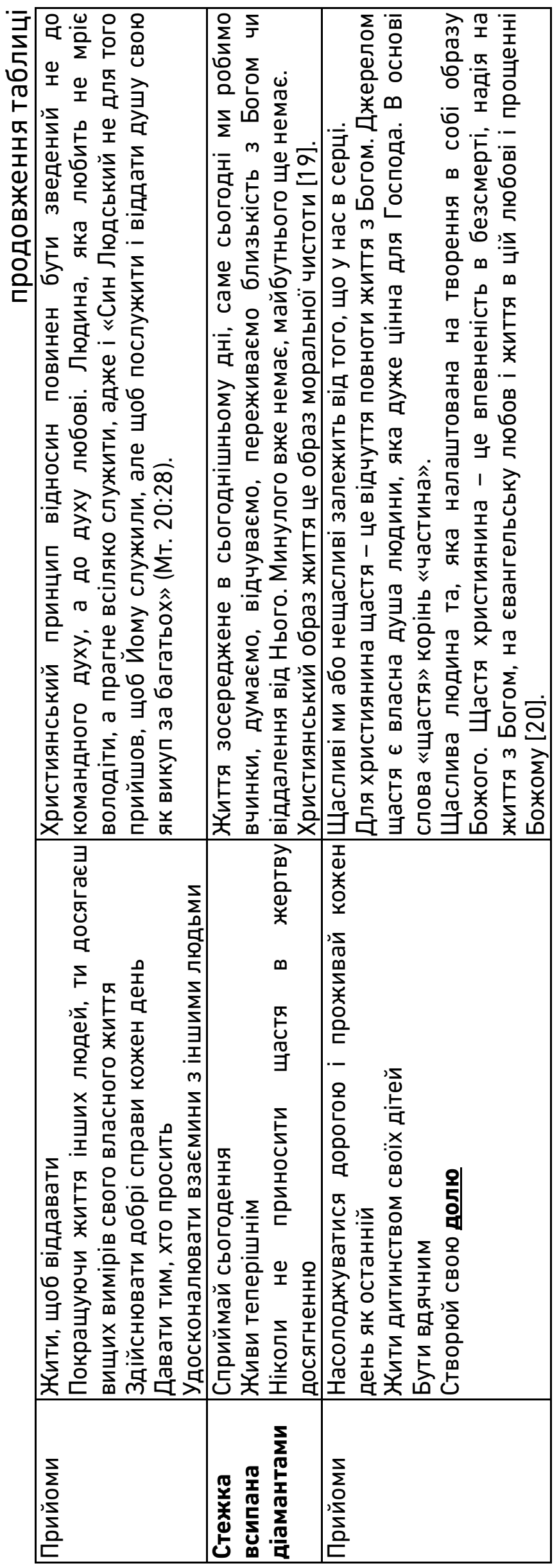


Не знаючи християнських прийомів та принципів для самокерування та розвитку особистості часто люди приваблюються прийомами екзотичних релігій, тому подальша популяризація християнської моделі самоменеджменту формування та їі удосконалення, підтверджують прикладний характер результатів даного дослідження. Крім цього, однозначно, для нашого регіону, ментальності, життєвого укладу притаманний християнський світогляд.

Резюмуючи вищесказане, використовуючи процедуру порівняння вдалося закласти фундаментальні основи моделі самоменеджменту на основі християнської етики, дослідження якої $€$ перспективним 3 огляду на кількість послідовників даного віросповідання у світі загалом. Популяризація буддизму призвела до того, що багато інфлюенсерів вважають його філософією, що зможе відповідати сучасним науковим потребам. 3 огляду на дану тезу, можна зробити припущення, що християнство має всі можливості, для того щоб концептуально конкурувати з буддизмом у науковому плані, що у свою чергу призведе до розвитку подальших досліджень у само менеджменті.

1. Бут Г. Наші люди в Голлівуді. 10 православних «зірок». URL: https://rivne.church.ua/2015/12/02/nashi-lyudi-v-gollivudi-10-pravoslavnixzirok/ (дата звернення: 20.02.2020). 2. Корольова М. Зірки-буддисти. URL: https://tsn.ua/lady/zvezdy/zvezdy/zirki-buddisti-1211745.html (дата звернення: 20.02.2020). 3. Савельєв Ю. Б. Аналіз порівняльний у соціології. Велика українська енциклопедія. URL: https://vue.gov.ua/Аналіз_порівняльний_у_соціології (дата звернення: 20.02.2020). 4. Нетепчук В. В. Самоменеджмент : навч. посібник. Рівне : НУВГП, 2013. 354 с. 2 5. Робін Шарма. URL: https://uk.wikipedia.org/wiki/\%D0\%A0\%D0\%BE\%D0\%B1\%D1\%96\%D0\%BD_\%D0\%A8 \%D0\%B0\%D1\%80\%D0\%BC\%D0\%B0 (дата звернення: 20.02.2020). 6. Калугин P. Все про Робин Шарма. URL: https://romankalugin.com/vse-pro-robin-sharma-skachatvse-knigi-robin-sharma/ (дата звернення: 20.02.2020). 7. Робін Шарма. Біографія. URL: https://www.yakaboo.ua/ua/author/view/Robin_Sharma/ (дата звернення: 20.02.2020). 8. Робин Шарма. Биография. URL: https://24smi.org/celebrity/99387robin-sharma.html (дата звернення: 20.02.2020). 9. Робин С. Шарма. Монах, который продал свой «Феррари» / пер. с англ. К. Вронский. Изд. София, 288 с. 10. Витовицкий Ф. Каковы твои мысли, такова и жизнь твоя... / пер. с серб. А. Логинова. Минск : «Издательство Дмитрия Харченко, 2014. 11. Добротолюбие : в 5 т. 2-е изд., стер. Краматорск : Тираж-51, 2009. 560 с. Т. 3. 12. Затворник Ф. Страсти и борьба с ними: выдержки из творения и писем / соств. игумен Феофан Крюков. М. : Даниловский благовестник, 2003. 328 с. 13. Беседа преподобного Серафима Саровского о цели христианской жизни с симбирским помещиком и совестным судьей Николаем Александровичем Мотовиловым (из рукописных воспоминаний Н.A. Мотовилова). URL: http://serafim.kiev.ua/index.php?option=com_content\&view=article\&id=100\&ltemid $=1$ 7 (дата звернення: 20.02.2020). 14. Ткачов А. Мы вечны! Даже если этого не хотим. Родное слово, 2009. URL: https://azbyka.ru/fiction/my-vechny-dazhe-esli-etogone-xotim-kniga-1-protoierej-andrej-tkachev/ (дата звернення: 20.02.2020). 
15. Кови С. Р. Семь навыков высокоэффективных людей: мощные инструменты развития личности / пер. с англ. 12-е изд., под. М. : Альпина Паблишер, 2017. 396 с. 16. Протопресвітер Фома Хопко. 55 принципів християнського життя. URL: https://pravoslavie./112409.html (дата звернення: 20.02.2020). 17. Сигутин A. «Бодрствуйте, стойте в вере, будьте мужественны, тверды» беседа с иереем Алексием Зайцевым. URL: https://pravoslavie.ru/33061.html (дата звернення: 20.02.2020). 18. Архангельський Г. У времени в плену. Фома. URL: https://foma.ru/u-vremeni-v-plenu.html (дата звернення: 20.02.2020). 19. Горошкова Н. В чем смысл жизни, как найти свое предназначение. URL: https://pravlife.org/ru/content/v-chem-smysl-zhizni-kak-nayti-svoe-

prednaznachenie (дата звернення: 20.02.2020). 20. Сугутин А. 0 книге А. Лоргуса. Книга о счастье. Православный взгляд на счастье. Вестник : газета. № 4. 2014. URL: http://www.pafnuty-abbey.ru/publishing/7683/ (дата звернення: 20.02.2020). 21. Незговорова Г. Дієтолог розповіла, чим загрожує абсолютна відмова від продуктів тваринного походження. URL: https://1plus1.ua/snidanok-z-11/novyny/mifi-ta-pravda-pro-siroidinna-poradi-dietologa (дата звернення: 20.02.2020).

\section{REFERENCES:}

1. But H. Nashi liudy $v$ Hollivudi. 10 pravoslavnykh «zirok». URL: https://rivne.church.ua/2015/12/02/nashi-lyudi-v-gollivudi-10-pravoslavnix-zirok/ (data zvernennia: 20.02.2020). 2. Korolova M. Zirky-buddysty. URL: https://tsn.ua/lady/zvezdy/zvezdy/zirki-buddisti-1211745.html (data zvernennia: 20.02.2020). 3. Saveliev Yu. B. Analiz porivnialnyi u sotsiolohii. Velyka ukrainska entsyklopediia. URL: https://vue.gov.ua/Analiz_porivnialnyi_u_sotsiolohii (data zvernennia: 20.02.2020). 4. Netepchuk V. V. Samomenedzhment : navch. posibnyk. Rivne : NUVHP, 2013. 354 s. 5. Robin Sharma. URL: https://uk.wikipedia.org/wiki/\%D0\%A0\%D0\%BE\%D0\%B1\%D1\%96\%D0\%BD_\%D0\%A8 \%D0\%B0\%D1\%80\%D0\%BC\%D0\%B0 (data zvernennia: 20.02.2020). 6. Kaluhyn R. Vse pro Robyn Sharma. URL: https://romankalugin.com/vse-pro-robin-sharma-skachatvse-knigi-robin-sharma/ (data zvernennia: 20.02.2020). 7. Robin Sharma. Biohrafiia. URL: https://www.yakaboo.ua/ua/author/view/Robin_Sharma/ (data zvernennia: 20.02.2020). 8. Robin Sharma. Biohrafiia. URL: https://24smi.org/celebrity/99387robin-sharma.html (data zvernennia: 20.02.2020). 9. Robin S. Sharma. Monakh, kotoryi prodal svoi «ferrari» / per. s anhl. K. Vronskii. Izd. Sofiia, 288 s. 10. Vitovitskii F. Kakovy tvoi mysli, takova i zhizn tvoia... / per. s serb. A. Lohinova. Minsk: «lzdatelstvo Dmitriia Kharchenko, 2014. 11. Dobrotoliubie v 5 t. 2-e izd. ster. Kramatorsk: Tirazh 51, 2009. T. 3. 560 s. 12. Zatvornik F. Strasti i borba s nimi: vyderzhki iz tvoreniia i pisem / sostv. ihumen Feofan Kriukov. M. : Danilovskii blahovestnik, 2003. 328 s. 13. Beseda prepodobnoho Serafima Sarovskoho o tseli khristianskoi zhizni $s$ simbirskim pomeshchikom i sovestnym sudei Nikolaem Aleksandrovichem Motovilovym (iz rukopisnykh vospominanii N.A. Motovilova). URL: http://serafim.kiev.ua/index.php?option=com_content\&view=article\&id=100\&ltemid=1 7 (data zvernennia: 20.02.2020). 14. Tkachov A. My vechny! Dazhe esli etoho ne khotim. Rodnoe slovo, 2009. URL: https://azbyka.ru/fiction/my-vechny-dazhe-eslietogo-ne-xotim-kniga-1-protoierej-andrej-tkachev/ (data zvernennia: 20.02.2020). 15. Kovi S. R. Sem navykov vysokoeffektivnykh liudei: moshchnye instrumenty razvitiia lichnosti / per. s anhl. 12-e izd., pod. M. : Alpina Pablisher, 2017. 396 s. 16. Protopresviter Foma Khopko. 55 pryntsypiv khrystyianskoho zhyttia. URL: https://pravoslavie./112409.html (data zvernennia: 20.02.2020). 17. Sihutin A. 
«Bodrstvuite, stoite v vere, budte muzhestvenny, tverdy» beseda s iereem Aleksiem Zaitsevym. URL: https://pravoslavie.ru/33061.html (data zvernennia: 20.02.2020). 18. Arkhanhelskii H. U vremeni v plenu. Foma. URL: https://foma.ru/u-vremeni-vplenu.html (data zvernennia: 20.02.2020). 19. Horoshkova N. V chem smysl zhizni, kak naiti svoe prednaznachenie. URL: https://pravlife.org/ru/content/v-chem-smyslzhizni-kak-nayti-svoe-prednaznachenie (data zvernennia: 20.02.2020). 20. Suhutin A. 0 knihe A. Lorhusa. Kniha o schaste. Pravoslavnyi vzghliad na schaste. Vestnik : hazeta. № 4. 2014. URL: http://www.pafnuty-abbey.ru/publishing/7683/ (data zvernennia: 20.02.2020). 21. Nezghovorova H. Diietoloh rozpovila, chym zahrozhuie absoliutna vidmova vid produktiv tvarynnoho pokhodzhennia. URL: https:// 1 plus1.ua/snidanok-z-1-1/novyny/mifi-ta-pravda-pro-siroidinna-poradidietologa (data zvernennia: 20.02.2020).

Andriitso-Ruzaieva A. Yu., Assistant, Department of Management Zadorozhna I. D., Senior Student (National University of Water and Environmental Engineering, Rivne)

\section{COMPARATIVE ANALYSIS OF THE COMPONENTS OF SELF- MANAGEMENT ACCORDING TO THE R. S. SHARMA'S MODEL BASED ON THE CHRISTIAN WORLDVIEW}

The paper analyses and compares the focal components of selfmanagement models, which are actively used by different people, including public figures, who are known worldwide. The authors conducted a cross-cultural study of behaviours in the context of Hindu and Christian cultures, defining the nucleus of self-management and personal development for the representatives of the aforementioned cultures, their value orientations, as well as the centre of life, which, in its turn, is based on such fundamental principles as internal security, life orientation, wisdom and self-control. The scholars tested their comparison of the following seven components of Robin $S$. Sharma's self-management model, particularly: (1) thinking, thoughts, moods, desires; (2) mission, purpose of life; (3) application of a precise self-control model (scientists refer to it as «self-regulation»); (4) willpower development; (5) time management (including the strategy how to get more done in less time); (6) personal contribution to the lives of other human beings; (7) happy, joyful, rich, productive and satisfying life; with components based on Christian ethics and the worldview of Eastern Orthodox Christians. The study revealed common and distinctive structural elements of the compared models. The authors evidenced the value and validity of the Christian model of self-management, which has proven to have every reason and opportunity to compete conceptually and methodologically with various self-management models, particularly with the Buddhist ones. 
This, in its turn, testifies to the prospect and development of further research with regard to self-management in scientific terms, at least being unambiguous for those regions where mentality and lifestyle are formed on the basis of the Christian worldview. The use of the comparison procedure has laid the foundations for building a selfmanagement model based on Christian ethics. Furthermore, the further study of the noted model is surely appropriate given the number of followers of the aforementioned rite in the world at large.

Keywords: self-management model; constituents; comparison method and procedure; self-control methods; Christianity; Buddhism.

Андрийцё-Рузаева А. Ю., ассистент кафедры менеджмента, Задорожная И. Д., соискатель высшего образования первого (бакалаврского) уровня (Национальный университет водного хозяйства и природопользования, г. Ровно)

\section{СРАВНИТЕЛЬНЫЙ АНАЛИЗ СОСТАВЛЯЮЩИХ САМОМЕНЕДЖМЕНТА ПО МОДЕЛИ Р. С. ШАРМА НА ОСНОВЕ ХРИСТИАНСКОГО МИРОВОЗЗРЕНИЯ}

Статья посвящена анализу основных составляющих моделей самоменеджмента. Осуществлено кросс-культурное исследование приемов поведения в контексте индуизськой и христианской культур. Проведена апробация сравнения составляющих модели самоменеджмента Робина Шармы с составляющими, основанных на христианской этике. Выявлены общие и отличительные структурные элементы сравниваемых моделей.

Ключевые слова: модель самоменеджмента; составляющие; метод и процедура сравнения; приемы самоуправления; христианство; буддизм. 